Abstracta Iranica Abstracta Iranica

Revue bibliographique pour le domaine irano-aryen

Volume 23 | 2002

Comptes rendus des publications de $\mathbf{2 0 0 0}$

\title{
Biblical Period Personal Seals in the Shlomo Moussaieff Collection. Tel Aviv : Archaeological Center Publications, 2000. 228 p.
}

\section{Astrid Nunn}

\section{(2) OpenEdition}

1 Journals

\section{Édition électronique}

URL : http://journals.openedition.org/abstractairanica/35261

DOI : 10.4000/abstractairanica.35261

ISSN : 1961-960X

Éditeur :

CNRS (UMR 7528 Mondes iraniens et indiens), Éditions de l'IFRI

\section{Édition imprimée}

Date de publication : 15 mai 2002

ISSN : 0240-8910

Référence électronique

Astrid Nunn, "Biblical Period Personal Seals in the Shlomo Moussaieff Collection. Tel Aviv

Archaeological Center Publications, 2000. 228 p. », Abstracta Iranica [En ligne], Volume 23 | 2002,

document 68, mis en ligne le 08 février 2010, consulté le 25 septembre 2020. URL : http://

journals.openedition.org/abstractairanica/35261; DOI : https://doi.org/10.4000/abstractairanica

35261

Ce document a été généré automatiquement le 25 septembre 2020.

Tous droits réservés 


\title{
Biblical Period Personal Seals in the
} Shlomo Moussaieff Collection. Tel Aviv

: Archaeological Center Publications, 2000. 228 p.

\author{
Astrid Nunn
}

1203 sceaux dont traités dans cette publication. Tous proviennent du marché. La plupart remontent à l'époque du Fer. Les $\mathrm{n}^{\circ} 98$ et 101 sont phéniciens d'époque achéménide, le $\mathrm{n}^{\circ} 115$ (authentique ?) est araméen ainsi que le sceau cylindre $\mathrm{n}^{\circ} 116$. Reste pour cette époque le cachet $n^{\circ} 149$ (authentique ?).

\section{INDEX}

Thèmes : 3.2.2. Pré-Achéménides et Achéménides

\section{AUTEURS}

ASTRID NUNN

Université de Munich - Allemagne 